JURNAL HUMANIORA

TEKNOLOGI

Vol. II No.I; Oktober 2016

\title{
ANALISIS POTENSI ZAKAT DALAM UPAYA PENGENTASAN KEMISKINAN DI KALIMANTAN SELATAN
}

\author{
NOOR AMELIA \\ Jurusan Mesin Otomotif, Politeknik Negeri Tanah Laut \\ Jl. A. Yani, km 06, Ds. Panggung, kec. Pelaihari, Kab. Tanah Laut, Kalimantan Selatan \\ e-mail:noor.amelia2012@gmail.com
}

\begin{abstract}
Abstrak
Permasalahan kemiskinan merupakan salah satu masalah penting dalam pembangunan ekonomi di Indonesia khususnya Provinsi Kalimantan Selatan. Salah satu upaya untuk menekantingkat kemiskinan adalah dengan memaksimalkan potensi zakat, karena mayoritas penduduk di Kalimantan Selatan adalah muslim. Zakat, di samping sebagai rukun Islam yang ketiga dan bagian dari ibadah mahgdah kepada Allah s.w.t., zakat juga merupakan ibadah maliyah yang memiliki berbagai fungsi sosial yang strategis dalam rangka meningkatkan kesejahteraan umat. Berdasarkan data yang dihimpun Badan Amil Zakat Kalsel hanya sekitar 1 (satu) persen dari potensi zakat yang adama kapotensi zakat di Kalimantan Selatan diperkirakan mencapai lebih dari 200 milyar per tahun. Pemberdayaan zakat khususnya zakat produktif diharapkan mampu menjadi solusi untuk mengentaskan kemiskinan di daerah Kalimantan Selatan, dan juga seluruh provinsi lainnya di Indonesia.
\end{abstract}

Kata kunci: zakat, pengentasan kemiskinan

\section{PENDAHULUAN}

Permasalahan kemiskinan merupakan salah satu masalah penting dalam pembangunan ekonomi di Indonesia khususnya Provinsi Kalimantan Selatan. Padahal, program pengentasan kemiskinan selalu tercantum dalam program pembangunan dari waktu ke waktu, dengan dana penanggulangan kemiskinan yang terus meningkat. Berdasarkan Berita Resmi Statistik BPS Provinsi Kalimantan Selatan, tingkat kemiskinan di Kalimantan Selatan keadaan Maret 2016 tercatat 4,85 persen naik 0,13 poin dibandingkan September 2015 yang sebesar 4,72 persen. Pada Maret 2016, persentase penduduk miskin di daerah perkotaan 3,48 persen dan di perdesaan 5,89 persen. 
Pembangunan ekonomi merupakan program terarah pemerintah dalam memanfaatkan sumber daya yang ada baik sumber daya alam maupun sumber lain yang di peroleh dari rakyatnya seperti pajak dan zakat untuk mencapai program tersebut. Pembangunan di sini bukan sebuah tujuan melainkan hanya sebuah instrumen sebagai proses untuk menurunkan kemiskinan dan mengurangi ketimpangan distribusi pendapatan. Jika pertumbuhan ekonomi yang tinggi namun tidak di ikuti distribusi pendapatan maka tidak dapat mengurangi ketimpangan pendapatan. Oleh karena itu, dalam konsep ekonomi Islam di tawarkan instrumen distribusi pendapatan yang adil yaitu salah satunya adalah zakat.

Muhammad Chaudhry (2012) mengemukakan bahwa zakat adalah pungutan atau pajak wajib yang dikumpulkan oleh negara Islam dari si kaya dan didistribusikan atau dikeluarkan kepada si miskin. Meskipun objek zakat sama dengan objek pajak yaitu sama-sama di ambil dari masyarakat, namun dalam konsep zakat menyebutkan bahwa zakat hanya di peruntukan bagi harta yang telah mencapai nisab dan haul. Selain itu, besarnya zakat bersifat tetap karena sudah di tentukan oleh nash dalam Al-quran. Zakat sebagai rukun Islam yang ketiga merupakan kewajiban yang harus di keluarkan oleh umat Islam untuk membersikan baik harta (zakat maal) maupun dirinya (zakat fitrah). Di negara yang sebagian besar penduduknya muslim seperti Indonesia ini, potensi zakat sangatlah besar untuk mendukung pembangunan ekonomi dalam rangka untuk mencapai kesejahteraan.

Potensi zakat di Indonesia sangatlah besar, di perkirakan mencapai Rp217 triliun namun kenyataanya yang terkumpul hanya sekitar 1\%nya. Ketua Forum Zakat (FOZ), Bramasetia menjelaskan pertumbuhan pasar zakat di tanah air terus meningkat setiap tahun mencapai 30\%-40\%. Pada 2012 dana zakat yang terkumpul sekitar Rp2,2 triliun dan meningkat di tahun 2013 menjadi Rp2,4 triliun. Meskipun realitanya jauh dari yang diperkiran namun di yakini tren positif ini akan terus berlanjut mengingat pemerintah sudah semakin serius mengelola zakat secara nasional, hal ini di buktikan dengan adanya Undang-undang terbaru Nomor 23 Tahun 2011 tentang Pengelolaan Zakat. Proses penghimpunan, pendistribusian dan pendayagunaan zakat yang optimal di percaya oleh beberapa ahli ekonomi Islam mampu menjadi solusi pengentasan kemiskinan di Indonesia.

Potensi zakat di Kalimantan Selatan (Kalsel) ternyata cukup besar. Diperkirakan potensi zakat masyarakat Banua bisa mencapai ratusan miliar. Kepala Bidang Penerangan Agama Islam, Zakat, dan Kanwil Kementerian Agama Provinsi Kalsel, 
Salman mengungkapkan mayoritas masyarakat Kalsel sudah sadar bahwa zakat adalah kewajiban bagi yang sudah memenuhi perhitungan. Namun zakat yang dikeluarkan oleh masyarakat tak semuanya disalurkan melalui lembaga resmi.

\section{METODE PENELITIAN}

Penelitian ini menggunakan metode deskriptif kualitatif. Penelitian ini bertujuan untuk menggambarkan, meringkaskan berbagai kondisi, berbagai situasi atau berbagai fenomena realitas sosial yang ada di masyarakat yang menjadi objek penelitian, dan berupaya menarik realitas itu kepermukaan sebagai suatu ciri, karakter, sifat, model, tanda, atau gambaran tentang kondisi, situasi, ataupun fenomana tertentu (Bungin, 2008:68).

\section{HASIL DAN PEMBAHASAN}

\section{Gambaran Potensi Zakat di Indonesia}

Umat Islam itu memiliki berbagai persoalan yang berat dan kompleks, seperti persoalan pemahaman agama yang belum lurus, persoalan kemiskinan yang masih melilit sebagian besar umat, persoalan kebodohan dan sebagainya, umat Islam pun memiliki banyak potensi yang belum digali dan belum di manfaatkan secara optimal untuk mengatasi persoalan-persoalan tersebut, sekaligus untuk membangkitkan kembali peradaban Islam di era globalisasi ini. Potensi tersebut antara lain adalah zakat, infak, sedekah dan wakaf (ZISWAF) yang tersebar merata di negara-negara mayoritas penduduknya muslim tak terkecuali muslim di wilayah Kalimantan Selatan yang berkisar $96,67 \%$.

Zakat, di samping sebagai rukun Islam yang ketiga dan bagian dari ibadah mahgdah kepada Allah s.w.t., juga merupakan ibadah maliyah yang memiliki berbagai fungsi sosial yang strategis dalam rangka meningkatkan kesejahteraan umat. Secara empirik, hal ini pernah terbukti dalam sejarah pada masa Khalifah Umar bin Abdul Azis. Ketika itu, zakat dikelola oleh para petugas (amil zakat) yang amanah dan profesional, di bawah kendali pemerintah yang adil dan bertanggung jawab, ternyata telah mampu meningkatkan kesejahteraan umat dan meminimalisir hal-hal yang berkaitan dengan kemiskinan dalam waktu yang relatif tidak lama.

Menurut data Badan Pusat Statistik (BPS) pada bulan Maret 2016 jumlah penduduk miskin (penduduk dengan pengeluaran per kapita per bulan di bawah garis 
kemiskinan) di Kalimantan Selatan mencapai 195.700 orang. Lebih jelasnya dapat kita lihat pada tabel berikut:

Jumlah dan Presentase Penduduk Miskin

September 2015-Maret 2016

Daerah/Tahun

(1)
Jumlah penduduk miskin

(Orang)

(2)
Presentase Penduduk Miskin (\%)

3)

\section{Perkotaan}

September 2015

72.481

4,27

Maret 2016

60.826

3,48

\section{Pedesaan}

September 2015

116.682

5,06

Maret 2016

134.875

5,89

Perkotaan + Pedesaan

September 2015

189.163

4,72

Maret 2016

195.700

4,85

Sumber: Diolah dari Data BPS Kalimantan Selatan September 2015 dan Maret 2016

Dari data kemiskinan di atas dapat menjadi gambaran jumlah orang miskin di Kalimantan Selatan yang mayoritas dari orang miskin tersebut adalah beragama Islam. Jumlah penduduk Kalimantan Selatan menurut BPS tahun 2016 sekitar 4.055.479 jiwa, dari jumlah itu 3.505.846 jiwa adalah beragama Islam. Seperti di singgung di uraian sebelumnya potensi zakat di Kalimantan Selatan mencapai 400 miliyar, jika ini di optimalkan penghimpunannya dan di salurkan kepada delapan asnaf maka tidak di pungkiri bahwa jumlah muzakki di Kalimantan Selatan. Delapan asnaf yang wajib menerima zakat terdapat dua objek yang harus mejadi problema bangsa indonesia selama ini yaitu kemiskinan dan pengangguran (fakir). 


\section{Cara Merealisasikan Zakat sebagai Program Pengentasan Kemiskinan}

Dalam zakat terdapat unsure mengembangkan sikap gotong-royong dan tolongmenolong. Sebab zakat dapat membantu orang-orang yang terjepit kebutuhan dan membatu menyelesaikan hutang bagi orang-orang yang sedang pailit. Zakat juga menolong orang-orang yang sedang dalam perantauan, pengungsi, sampai orang tua yang pikun atau jompo. Dengan zakat pula, dakwah Islam dapat diperluas cakupannya, termasuk untuk menjinakkan hati para muallaf. Misi sosial zakat yang begitu idealis tersebut tidak dapat dipenuhi dengan baik tanpa adanya lembaga pengelolaan zakat yang dijalankan secara profesional. Menurut Qardhawi zakat merupakan salah satu dari aturan jaminan social dalam Islam, dan Islam memperkenalkan aturan ini dalam ruang lingkup lebih luas dan mendalam yang mencakup semua segi kehidupan manusia.

Oleh karena itu, pola hubungan antara orang kaya dan orang miskin harus dibangun secara sistemik dan terprogram dengan menggunakan system jaminan social pembangunan ekonomi umat. Karena, secara normative konseptual, Islam mengajarkan kerangka dasar pola hubungan antara si-kaya dan si-miskin dalam konsep kepemilikan harta benda dan system ini dalam komunitas muslim dikenal dengan istilah zakat.

Menurut Permono pelaksanaan zakat pada hakikatnya merupakan usaha untuk: (1) Membersihkan jiwa muzakki (wajib zakat) dari pada sifat-sifat bakhil, loba dan tamak serta menanamkan rasa kesetiakawanan (solidaritas) terhadap golongan mustadzafin. (2) Membersihkan harta yang kotor karena campur dengan harta mustahiq (orang yang berhak menerima). (3) Menumbuh kembangkan kekayaan muzakki sebagaimana firman Allah dalam Al-qur'an: "Siapakah yang mau memberikan pinjaman kepada Allah, pinjaman yang baik (menafkahkan hartanya dijalan Allah), maka Allah akan memperlipatgandakan pembayaran kepadanya dengan lipat ganda yang banyak, Ddan Allah menyempitkan dan melapangkan (rizki) dan kepada-Nyalah kamukembali", Al-qur'an Surat Al Baqarahayat 245. (4) Membersihkan jiwa para mustahiq (orang yang berhak menerima zakat) dari perasaan sakit hati, benci, dan dendam terhadap golongan orang-orang kaya yang hidup dalam serba kemewahan tetapi tidak sudi mengeluarkan zakat. (5) Memberikan modal kerja kepad agolongan lemah (melarat) untuk menjadi manusia yang berkemampuan hidup layak.

Untuk merealisasikan Program Pengentasan Kemiskinan malalui zakat sebagai model alternatif yang akan dilakukan, adalah: (1) Amil zakat, melakukan pemetaan terhadap sumber-sumber zakat (termasuk memberikan layanan bantuan penghitungan terhadap harta wajib zakat dan jumlah zakat yang akandibayarkan/dikeluarkan oleh 
muzakki), dan potensi yang dimiliki oleh para mustahiq. (2) Mengorganisir mustahiq. (3) Menyelenggarakan pelatihan tentang pengembangan masyarakat (community development) bagi para mustahiq dengan target (output) mereka mampu merumuskan persoalan yang dihadapi dan dapat memilih alternatif solusinya. (4) Realisasi program, monitoring dan evaluasi.

\section{Pendistribusian Zakat}

Pendistribusian adalah suatu kegiatan dimana zakat bisa sampai kepada mustahiq secara tepat. Kegiatan pendistribusian sangat berkaitan dengan pendayagunaan, karena apa yang akan didistribusikan disesuaikan dengan pendayagunaan. Akan tetapi juga tidak bisa terlepas dari penghimpunan dan pengelolaan. Jika penghimpunannya tidak maksimal dan mungkin malah tidak memperoleh dana zakat sedikitpun maka tidak akan ada dana yang didistribusikan.

Muhammad (2006:176) berpendapat bahwa distribusi zakat berkaitan dengan persediaan, saluran distribusi, cakupan distribusi, lokasi mustahiq, wilayah penyaluran, tingkat persediaan, dana zakat dan lokasi amil, pengiriman, dan keagenan.

Zakat yang dihimpun oleh Lembaga Zakat harus segera disalurkan kepada para mustahiq sesuai dengan skala prioritas yang telah disusun dalam program kerja. Mekanisme distribusi zakat kepada mustahiq bersifat konsumtif dan juga produktif. Menurut Mufraini (2006: 148) distribusi zakat tidak hanya dengan dua cara akan tetapi ada tiga yaitu: distribusi konsumtif, distribusi produktif, dan investasi.

Untuk mengentaskan kemiskinan maka dalam pendistribusiannya zakat lebih di fokuskan pada distributif sehingga dapat berdampak jangka panjang dan juga berimplikasi pada peningkatan aset mustahiq. Penditribusian zakat secara produktif misalnya:

(1) Distribusi Zakat Bersifat Produktif Tradisional. Zakat diberikan dalam bentuk barang-barang yangproduktif seperti kambing, sapi, alat cukur, dan lain sebagainya. Pemberian dalam bentuk ini akan dapat menciptakan suatu usaha yang membuka lapangan kerja fakir miskin.

(2) Distribusi Zakat dalam Bentuk Produktif Kreatif. Zakat diwujudkan dalam bentuk permodalan baik untuk membangun proyek sosial atau menambah modal dagang pengusaha kecil. Sebagimana dilihat dari inovasi di atas maka lembaga zakat selain mendistribusikan zakat secara konsumtif, saat ini juga telah mengembangkan sistem distribusi zakat produktif. Pola distribusi dana zakat produktif menjadi menarik 
untuk dibahas mengingat ketentuan syarieah menegaskan bahwa dana zakat yang terkumpul sepenuhnya adalah hak milik dari mustahiq delapan asnaf. Zakat bukan hanya persoalan ibadah mahdah (ritual murni) tapi juga persoalan maliyah ijtima'iyyah (harta benda sosial) oleh karenanya harus ma'qulul ma'na (masuk akal). Ini merupakan pendapat golongan Hanafiyah dan pendapat ini dapat diterima karena ma'qulul ma'na dapat diterapkan sesuai perkembangan zaman. Dan dapat menjawab tuntutan kemaslahatan umat, kapanpun dan dimanapun. Al-Qur'an sendiri tidak mengatur bagaimana seharusnya dan sebaiknya membagikan zakat kepada para asnaf. Umar bin Khattab r.a. pernah memberikan dana zakat berupa kambing agar dapat berkembang biak. Nabi pernah memberikannya kepada seorang fakir sebanyak dua dirham, dengan memberikan anjuran agar mempergunakan uang tersebut, satu dirham untuk dimakan dan satu dirham lagi supaya dibelikan kapak sebagai alat kerja. Berdasarkan pendapat golongan Hanafiyah, dan peristiwa pada masa Rasulullah dan Umar maka distribusi zakat secara produktif diperbolehkan demi kemaslahatan umat. Pendapat ini dikuatkan oleh Yafie (1995:236) bahwa pemanfaatan dana zakat yang dijabarkan dalam ajaran Fiqih memberi petunjuk perlunya suatu kebijakan dan kecermatan, di mana perlu dipertimbangkan faktorfaktor pemerataan dan penyamaan, kebutuhan yang nyata dari kelompok-kelompok penerima zakat, kemampuan penggunaan dana zakat dari yang bersangkutan yang mengarah kepada peningkatan kesejahteraannya dan kebebasannya dari kemelaratan, sehingga pada gilirannya yang bersangkutan tidak lagi menjadi penerima zakat tetapi menjadi pembayar zakat. Hal-hal di atas dicontohkan bahwa jika penerima zakat tersebut tahu dan biasa berniaga maka kepadanya diberikan modal usaha, atau yang bersangkutan mempunyai keterampilan pertukangan maka kepadanya diberikan perkakas yang memungkinkan dia bekerja dalam bidang keterampilannya untuk memenuhi kebutuhan hidupnya. Terhadap dana zakat tersebut tidak akan menjadi permasalahan yang ilegal dalam pengertian hukum. Oleh karena itu dana zakat yang digulirkan secara produktif tentunya tidak dapat menuntut adanya tingkat pengembalian tertentu sebagaimana halnya sumber dana selain zakat. Konsep distribusi dana zakat secara produktif yang dikedepankan sejumlah lembaga zakat biasanya dipadukan dengan dana terkumpul lainnya yaitu dana infak, sedekah dan wakaf.

Dengan penditribusian yang selain bersifat konsumtif tetapi juga produktif maka dampak zakat akan lebih bermanfaat,tidak hanya sekedar penggugur kewajiban bagi 
muzakki tetapi menjadi salah instrumen sosial untuk menciptakan kesejahteraan.

\section{KESIMPULAN}

Berdasarkan Berita Resmi Statistik BPS Provinsi Kalimantan Selatan, Tingkat kemiskinan di Kalimantan Selatan keadaan Maret 2016 tercatat 4,85 persen naik 0,13 poin dibandingkan September 2015 yang sebesar 4,72persen. Pada Maret 2016, persentase penduduk miskin di daerah perkotaan 3,48 persen dan di perdesaan 5,89 persen. Sedangkan jumlah penduduk Kalimantan Selatan menurut BPS tahun 2016 sekitar 4.055.479 jiwa, dari jumlah itu 3.505.846 jiwa adalah beragama Islam. Seperti di singgung di uraian sebelumnya potensi zakat di Kalimantan Selatan mencapai 400 miliyar, jika ini di optimalkan penghimpunannya dan di salurkan kepada delapan asnaf maka tidak di pungkiri bahwa jumlah muzakki di Kalimantan Selatan. Delapan asnaf yang wajib menerima zakat terdapat dua objek yang harus mejadi problema bangsa indonesia selama ini yaitu kemiskinan dan pengangguran (fakir).

Untuk mengentaskan kemiskinan maka dalam pendistribusiannya zakat lebih di fokuskan pada distributif sehingga dapat berdampak jangka panjang dan juga berimplikasi pada peningkatan aset mustahiq. Penditribusian zakat secara produktif misalnya distribusi zakat yang bersifat produktif tradisional dan kreatif.

\section{DAFTAR PUSTAKA}

Andriyanto, Irsyad. Strategi Pengelolaan Zakat dalam Pengentasan Kemiskinan. STAIN Kudus, Walisongo, Volume 19, Nomor 1, Mei 2011.

Chaudhry, Muhammad Sharif. 2012. Prinsip Dasar Sistem Ekonomi Islam (Terjemahan). Jakarta: Kencana Prenada Media Group.

El-Madani. 2013. Fiqih Zakat Lengkap: Segala Hal tentang Kewajiban Zakat dan Cara Membaginya. Jogjakarta: Diva Press.

Ernawati, Hasti. Zakat sebagai Sarana Pengentasan Kemiskinan (Studi Kasus di Lembaga Amil Zakat "Bina Umat Mandiri” Kabupaten Ngawi).

Hasrullah. 2012. Efektivitas Pelaksanaan Zakat di Badan Amil Zakat Kota Palopo. Makassar: Skripsi Universitas Hasanudin tidak Dipublikasikan.

http://kalsel.bps.go.id/(diunduh tanggal 12 November 2016).

http://www.banuasyariah.com/2014/07/potensi-zakat-kalsel-tembus-rp200.html

(di akses tanggal 12 November 2016). 
Qaradhawi, Yusuf. 2005. Spektrum Zakat dalam Membangun Ekonomi Kerakyatan. Jakarta: Zikrul Hakim.

Supriono. 2014. Peran Zakat dalam Mengentaskan Kemiskinan. Surabaya: Univesritas Airlangga.

Zakat dan Empowering. 2009. Jurnal Pemikiran dan Gagasan-Vol II.

Zakat, M. Ali. 2008. Zakat dan Infak: Salah Satu Solusi Problema Sosial di Indonesia. Jakarta: Kencana Prenada Media Group. 